\title{
The Relationship between Teachers' Competency and Fourth Industrial Revolution (4IR) Learning among Economics Teachers
}

\author{
Vera Aprianti, Sheerad Sahid* \\ Faculty of Education, Universiti Kebangsaan Malaysia (UKM), Malaysia
}

Received July 30, 2020; Revised October 26, 2020; Accepted October 30, 2020

\section{Cite This Paper in the following Citation Styles}

(a): [1] Vera Aprianti, Sheerad Sahid, "The Relationship between Teachers' Competency and Fourth Industrial Revolution (4IR) Learning among Economics Teachers, " Universal Journal of Educational Research, Vol. 8, No. 11A, pp. 63 - 70, 2020. DOI: 10.13189/ujer.2020.082108.

(b): Vera Aprianti, Sheerad Sahid (2020). The Relationship between Teachers' Competency and Fourth Industrial Revolution (4IR) Learning among Economics Teachers. Universal Journal of Educational Research, 8(11A), 63 - 70. DOI: 10.13189/ujer.2020.082108.

Copyright $\subseteq 2020$ by authors, all rights reserved. Authors agree that this article remains permanently open access under the terms of the Creative Commons Attribution License 4.0 International License

\begin{abstract}
Economic development of a country may not be achieved when the quality of its human resources is low. Therefore, teachers with high competencies contribute to the quality of the learning process in schools, especially in the era of Fourth Industrial Revolution (4IR) learning. This paper aims to examine the relationship between teachers' competencies and 4IR learning among economics teachers. A quantitative approach using self-administered questionnaires was employed. The units of analysis of the study were economics teachers in the central city of Jakarta, Indonesia. A total of 256 respondents from the sampling frame were selected using a simple random sampling technique. The data were analyzed by correlation and regression tests using IBM SPSS, Version 25. The results indicate that teachers' competency has a positive correlation and a significant effect on 4IR learning. The findings from the study contribute to the future development of economics teachers by shaping the quality of education. Teachers can also have more flexibility in designing their lessons creatively in the 4IR learning era.
\end{abstract}

Keywords Teacher Competency, Economics Teachers, Quality of Education, The Fourth Industrial Learning Era

\section{Introduction}

The role of teachers today is increasingly challenging.
They play a crucial role as communicators of knowledge and skills to students and are responsible for increasing students' interests and developing talents and abilities. Teachers are also relied upon to build analytical, critical, and creative thinking skills, in line with the education system's direction, to form individuals who can adapt to the changes that occur around them. The quality of education is inseparable from the quality of teachers. One effort used to improve the quality of education is to improve the professionalism of teachers. Teacher competence is needed to improve teacher professionalism and to improve the quality of national education. Indonesian Law No. 14 of 2005 was implemented to meet teacher professionalism demands.

Based on Indonesian Law No. 14 of 2005, teachers are required to have several competencies: pedagogical competencies, social competencies, personality competencies, and professional competencies. These competencies can be used to support the improvement of teachers' competencies in 4IR learning. In the time of the 4.0 industrial revolution, teachers are expected to be a vital part of improving the quality of education by firstly improving the competencies of teachers themselves. In order to ensure success in facing the Fourth Industrial Revolution, the ability to adapt to new technologies and global challenges is required, particularly for economics teachers. Every educational institution must provide new information and literacy in education, especially those 
related to preparation for the Fourth Industrial Revolution.

This paper provides a detailed explanation of the competence of economics teachers' conceptual framework for 4IR learning, starting with four teacher competencies. These are pedagogical competence (which is teachers' ability in the teaching and learning process of learning management), social competence (the ability of teachers to communicate and interact effectively and efficiently with students, fellow teachers, parents/guardians, and society), personality competencies (personal abilities that reflect a stable, mature, intelligent, and authoritative personality, acting as an example to students, and having a noble and solid character) and professional competence (the mastery of learning materials extensively and deeply). At the same time, all the competencies which impact 4IR learning are dependent on technology and school environment factors.

Today, challenges to teachers - especially economics teachers besides having to have 4 competencies (pedagogical, social, personality, and professional competence); can also include efforts to equip themselves with information and communication technology skills because, in this era, it is necessary to enable students to follow learning using technology. Therefore, teachers need to change their ways of teaching to make it more fun and interesting. Similarly, the teacher's role has changed from being a transmitter of knowledge to students, to becoming facilitators, motivators, inspirers, mentors, and developers of imagination, creativity, character, teamwork, and social empathy; otherwise, the role of teachers could be replaced by technology. The Industrial Revolution 4.0, which comprises extremely fast technology, is bringing about big changes in Indonesia's education system. Changes in the education system have an impact on the role of teachers as educators. Teachers must have high competencies to produce students who can answer the challenges of the Industrial Revolution 4.0.

The present study intends to provide information for relevant personnel in schools that can be used to improve the teaching of students. The study objectives are formulated as follows:

1. To identify the level of competency of economics teachers in terms of 4IR learning.

2. To examine the effect of economics teachers' competencies on 4IR learning.

\section{Literature Review}

Afrianto (2018) discusses how professional teachers in Indonesia can maintain their professionalism in a rapidly evolving world due to the developments caused by revolutionary information technology in the industrial world that has led to the rise of the Industrial Revolution 4.0 (IR 4.0). Some features of the IR 4.0 era are digitalization, the Internet of things, the Internet of people, big data, iCloud data, and artificial intelligence. All these new developments have had an impact on various sectors of life, including education. IR 4.0 can be negative, because it can threaten the existence of schools and teachers.

Meanwhile, in his study, Rosmani Ali (2018) states that IR 4.0 provides exposure to and explanations about the role of entrepreneurial competence as a mediator for readiness to apply entrepreneurial elements for teacher's educational instituted (TEI) lectures. The study's implications support the importance of internal entrepreneurial attitude and entrepreneurial competence in affecting the readiness of TEI lecturers to apply entrepreneurial elements. Overall, this study provides an alternative answer to how entrepreneurial competence among TEI lecturers can determine their readiness to apply entrepreneurial elements.

The concept of teacher competence is mostly discussed in very narrow dimensions, such as teacher planning, implementation, curriculum evaluation, and curriculum or school standards related to the task of teachers teaching in schools (Muhd Khaizer et al., 2020: Kiymet Selvi, 2016). Teacher competence should continue to be the subject of research and analysis, and it should be developed and updated. Therefore, pre-service teachers and in-service education should focus on understanding and applying teacher competencies. The future will be different from the past and present in some respects. Therefore, teachers need new competencies to overcome all these changes, and it is necessary to redefine teacher competencies.

The research paper of Hewagamage (2014) expressed that ICT based competency must be addressed irrespective of their core curriculum of study streams and it may help to improve the relevance and better employability. It is evident from the literature that unless the issue of ICT competency is addressed, it can itself be a barrier to students' learning. They have suggested that special funds be created to revamp the e-learning support centres at the faculty level for students and faculty/staff use. The findings in Tasir (2012) show that teacher's competency, teacher's confidence level and teacher's satisfaction toward ICT programmes are correlated among each other. And also it has indicated that teacher's satisfaction toward ICT training programme is a crucial factor that can increase the levels of the competency and confidence. Therefore, teachers in the industrial revolution era of 4.0, especially among economic teachers, should have four competencies such as Pedagogical Competency, Professional Competency, Social Competency and Competency Of Personality based on the Law in Indonesia No. 14 of 2005 to stimulate courage in achieving the learning objectives available in the framework of improving the quality of resources of the teachers themselves.

\subsection{Pedagogical Competency}

Pedagogical competency can be defined as the ability to understand students, design and implement learning, 
evaluate learning outcomes, and develop students to practice their various potentials. According to Law in Indonesia No. 14 of 2005 Pedagogical Competencies including:

a. Understanding the vision or goals of education, Developing curriculum, Learning Design, Evaluating learning outcomes, Mastering learning theory and educating learning principles.

b. Understand the various learning theories and learning principles that educate those related to the teaching subjects.

c. Implement various approaches, strategies, methods, and learning techniques that educate creatively in teachable subjects.

d. Leverage information and communication technology for the importance of maintenance of expansion activities that educate and facilitate the expansion of the potential of educated participants to analyze the various potentials that students have and can communicate effectively, forcibly, and engage with students.

e. Leverage on the results of assessment and evaluation for the importance of learning to perform reflective actions for increased learning qualities.

\subsection{Social Competency}

An effective Teacher Competency is a teacher who successfully brings their students to achieve teaching goals. Teaching in front of the classroom is an expression of interaction in the communications process. According to Teacher Law and Lecturers, social competency is the ability of teachers to communicate and interact effectively and efficiently with students, fellow teachers, elderly or guardians of students, and the surrounding community. Expressing social efficiency is the ability that a person needs to succeed in dealing with others. According to The Law in Indonesia No. 14 of 2005, Social Competency includes:
a. Oral and written communications, using communications and information technology
b. Strengthening professionalism through the teachers, both internally and throughout the education unit. peer-guidance process, peer studies among
c. Acting objectively and not discriminated against due to gender consideration, religion, race, fiscal conditions, family background, and socio-economic status
d. Leverage information and communication technology (ICT) to communicate and develop themselves.

\subsection{Personality Competency}

Personal competency is a personal ability that reflect a stable, mature, intelligent and authoritative personality, be an example to students, and have noble character. The stability which can be an example to students and society an also develop themselves in an effective manner. The Competency of Teacher Personality as an educator whose main task is teaching, has very influential personality traits on the success of human resource development. The personality of a solid teacher figure will provide a good example for students and society, so that the teacher will appear as someone who should be imitated or able to mnjadi role model for his students. According to The Law in Indonesia No. 14 of 2005 Personality Competency includes:

a. Demonstrate work ethics, high responsibilities, pride as teachers, and self-confidence.

b. Demonstrate high work ethics and responsibilities and Proud to be a teacher and believe in yourself.

c. Show themselves as a stable, adult, intelligent, and authoritative person.

d. Demonstrate work ethics and high responsibilities and understand the teacher's professional code of ethics.

e. Understanding, applying, and acting appropriately the teacher's professional code of ethics.

\subsection{Professional Competency}

Professional competency is the mastery of learning materials extensively and deeply, including the meaning of curriculum lessons in schools and scientific materials related to teachings behaviour, as well as mastery of scientific structure and methodology and being able to communicate and develop themselves using the latest technology to make effective and efficient learning in line with technology that is currently developing. Hence, Professional competency is the ability to master the subject broadly and deeply Dayangku Suraya et al. (2020). Stating professional competence is the various abilities necessary to realize itself as a professional teacher. Professional competencies include expertise in the areas of material mastery that must be taught and its methods, a sense of responsibility for the tasks and sense of equality with other peers. According to Law in Indonesia No. 14 of 2005 Professional Competencies include:

a. Develop creative learning materials capable of developing professionalism continuously.

b. Take reflective action and be able to communicate

c. Master materials, structures, concepts, and scientific minds that support the teaching subjects. As an example of economic teachers who can understand the materials, structures, concepts, and science thinking that support the subjects of the economy; display the benefits of Economic subjects so that economic students have more interest in economic subjects.

d. Continuously get performance. And be able to use performance outcomes to improve professionalism. 


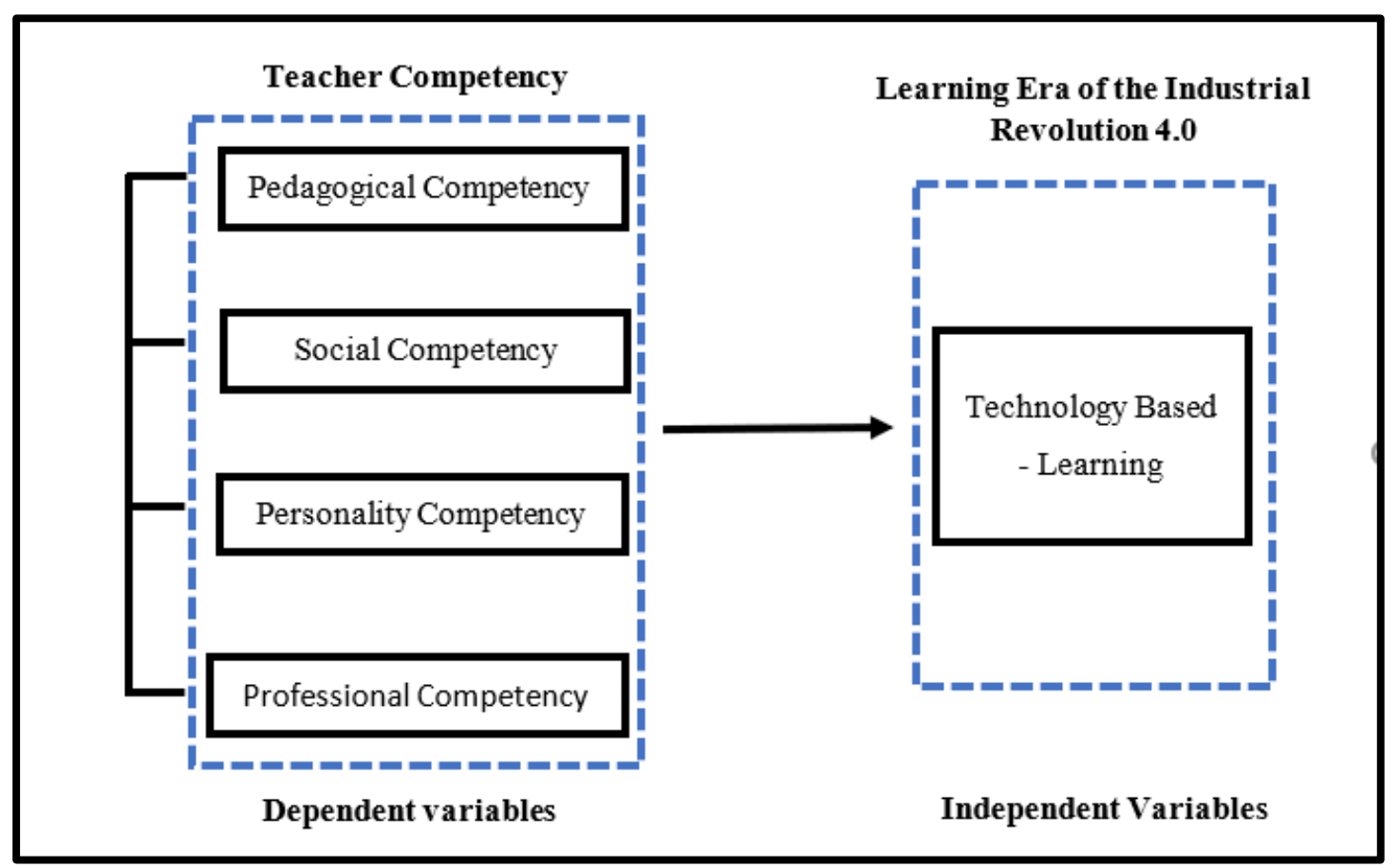

Figure 1. Conceptual Framework

Figure 1 is the conceptual framework for the present study. The framework was developed based on the Indonesian Law No. 14 of 2005 which explains the competencies that must be possessed by teachers to improve learning, such as pedagogical competencies, social competencies, personality competencies, and professional competencies. Kamarul Azmi (2016) stressed that an effective teacher's characteristics are to have teaching skills, including the ability to link knowledge, skills, and values in their teaching to the school environment. As such, this study's framework includes one dependent variable and one independent variable. The conceptual framework for this study is shown in Figure 1.

\section{Methodology}

\subsection{Participants}

In the following, the sampling and data analysis methods are identified so that the technique used can be shown to follow the study's objectives. Othman (2013) explains that, in determining sample size, various methods can be applied. The population concept refers to a group of individuals with criteria similar to the purpose of the study (Creswell 2008). In this study, Indonesian economics teachers were chosen as the population of this study. In selecting a sample, it is critical to determine the sample size to represent a population. The sample is a sub-group of the target population that is reviewed to represent the population. The sample consists of 256 Indonesian economics teachers from the eastern, southern, northern, western, and central parts of Jakarta. In this study, probability sampling was used as a basis for the sampling procedure. It was executed by selecting a subject randomly from the sampling frame; in this case, the subjects in the sample had all the features of the review population. Researchers then performed a simple random selection for each location to obtain the number of schools needed to represent the prescribed number of samples. A total of 50 economics teachers who were not involved in the actual study were selected in the pilot study.

\subsection{Research Procedure}

In this study, the researchers chose the quantitative screening method, which allows researchers to scrutinize data using statistical approaches. In this way, researchers can know the necessary information and measure identified variables. This study was conducted using a survey method. A survey study was used to obtain information in the form of opinions, attitudes, and perceptions of a population based on selected samples (Creswell 2005). The information in this study was obtained through a modified questionnaire from several previous studies. However, this section's questionnaire has been processed and modified according to the needs of the study based on EFA testing and expert consent. A pilot study was also conducted (sample $n=50$ ) to determine the validity and reliability of the study instrument. The result of pilot study on Table 1 indicated that all constructs measured in the instrument have a high-reliability value $(\alpha \geq 0.70)$. At the same time, experienced lecturers and experts in economic studies also gave their feedback on the importance, appropriateness, and accuracy of the content and clarity of the meaning of each item in this study instrument. 
Table 1. Instrument Reliability

\begin{tabular}{cc}
\hline Construct & Cronbach's Alpha (a) \\
\hline Pedagogical Competency & 0.869 \\
Social Competency & 0.835 \\
Personality Competency & 0.790 \\
Professional Competency & 0.793 \\
Technology Based - Learning & 0.837 \\
\hline
\end{tabular}

This study was conducted on economics teachers with regard to 4IR learning in Jakarta, Indonesia. Therefore, this section discusses the demographic background of economics teachers based on gender, age, level of education, total years of teaching experience, use of ICT, and use of social media. Table 2 shows in detail the demographic profile of the respondents for this study.

Table 2. Demographic profile of the respondents

\begin{tabular}{|c|c|c|c|}
\hline Category & Information & $\mathbf{F}$ & $\%$ \\
\hline \multirow[t]{2}{*}{ Gender } & Male & 87 & $34 \%$ \\
\hline & Female & 169 & $66 \%$ \\
\hline \multirow[t]{4}{*}{ Age } & 20-30 years & 102 & $39.8 \%$ \\
\hline & $31-40$ years & 93 & $36.3 \%$ \\
\hline & $41-50$ years & 35 & $13.7 \%$ \\
\hline & Above 50 years & 26 & $10.2 \%$ \\
\hline Education & High School/Equivalent & 4 & $1.6 \%$ \\
\hline \multirow[t]{3}{*}{ Level } & Bachelor's Degree & 242 & $94.5 \%$ \\
\hline & Master's Degree & 9 & $3.5 \%$ \\
\hline & Doctor of Philosophy & 1 & $0.4 \%$ \\
\hline $\begin{array}{c}\text { Total } \\
\text { Teaching }\end{array}$ & $1-10$ years & 224 & $87.5 \%$ \\
\hline \multirow[t]{3}{*}{$\begin{array}{c}\text { Year } \\
\text { Experience }\end{array}$} & $11-20$ years & 9 & $3.5 \%$ \\
\hline & 21-30 years & 15 & $5.9 \%$ \\
\hline & $31-40$ years & 8 & $3.1 \%$ \\
\hline \multirow[t]{4}{*}{ Use of ICT } & MOOC & 47 & $18.4 \%$ \\
\hline & Blended Learning & 75 & $29.3 \%$ \\
\hline & Project-Based Learning & 118 & $46.1 \%$ \\
\hline & Other & 16 & $6.3 \%$ \\
\hline $\begin{array}{l}\text { Use of } \\
\text { Social }\end{array}$ & Facebook & 120 & $46.9 \%$ \\
\hline \multirow[t]{3}{*}{ Media } & Instagram & 110 & $43.0 \%$ \\
\hline & LinkedIn & 11 & $4.3 \%$ \\
\hline & Other & 15 & $5.9 \%$ \\
\hline
\end{tabular}

After the relevant data was obtained, the author then analyzed the data descriptively and inferentially using SPSS software. During analysis, comparisons were made between teachers based on gender and other demographic characteristics. Researchers also tested the data collected using statistical analysis techniques such as frequency, mean, correlation, and regression.

\section{Findings and Discussion}

\section{Objective 1: To identify the level of competency of economics teachers in terms of 4IR learning.}

Descriptive analysis was used to achieve the first objective, which was to identify the level of competence of economics teachers in 4IR learning in Jakarta. A self-administered questionnaire consisting 40 items were distributed to the respondents. Descriptive findings for all item are stated in Table 3.

Table 3 shows the mean scores for the level of competency of economics teachers in 4IR learning. All items received a very positive response with 40 items submitted, 40 items were at a high level, Meanwhile, nine items from the pedagogical competency construct had a total mean of 4.22 with the highest mean value belonging to item 3, worth 3.35 , and item 6 , worth 4.14 . The social competency construct had an overall mean score of 4.16 , with item 6 , worth 4.27 , having the highest value and item 2 , with a mean value of 4.02 , having the lowest value. The professional competency construct had a total mean value of 4.03; the highest mean values belonged to item 2 with a value of 4.37 , and item 9 with 3.86 was the lowest. The personality competency construct, with a total mean of 3.97 , had a highest mean value for item 3 , worth 4.18 ; item 5 had the lowest mean value, with 3.66.

At the same time, the 4IR learning construct and environmental factors had mean values of 4.00 and 4.17, respectively. The highest value in the 4IR learning construct was for item 6 , at 4.19 , while item 8 scored lowest, with 3.61. The overall mean values possessed by each construct were at a high level. Therefore, the competence of economics teachers demonstrates a high level of 4IR learning. 
Table 3. Standard Deviation, Mean, and Score Interpretation

\begin{tabular}{|c|c|c|c|}
\hline No & Item per Construct & SD & Mean \\
\hline & Pedagogical Competence & & \\
\hline 1 & I make teaching and learning plans, whether short or long term. & .80 & 4.25 \\
\hline 2 & I have targets that support learning activities. & .84 & 4.20 \\
\hline 3 & I do the teaching to the standard that applies. & .83 & 4.35 \\
\hline 4 & I demonstrate practical demonstration skills by connecting things to the realities of daily life. & .80 & 4.31 \\
\hline 5 & I make students feel interested in participating in learning. & .86 & 4.17 \\
\hline 6 & I provide feedback to students about the material presented. & .88 & 4.14 \\
\hline \multirow[t]{2}{*}{7} & I conduct a learning evaluation. & .89 & 4.17 \\
\hline & Overall Pedagogical Competency Score & & 4.22 \\
\hline & Social Competence & & \\
\hline 1 & I use oral language correctly. & .80 & 4.18 \\
\hline 2 & I participate in activities that make it possible to meet new people. & .91 & 4.02 \\
\hline 3 & I stimulate student motivation in learning. & .87 & 4.20 \\
\hline 4 & I make students active in learning by showing an open attitude towards student responses. & .91 & 4.23 \\
\hline 5 & I cultivate student spirit. & .85 & 4.11 \\
\hline 6 & I communicate with fellow teachers regarding teaching and learning. & .84 & 4.27 \\
\hline 7 & I use online social media chat to interact. & .92 & 4.24 \\
\hline \multirow[t]{2}{*}{8} & I use social media as an example for students. & .88 & 4.06 \\
\hline & Overall Social Competency Score & & 4.16 \\
\hline & Professional Competence & & \\
\hline 1 & I carry out learning in accordance with the planning. & .84 & 4.26 \\
\hline 2 & I steer learning towards the competencies to be achieved. & .78 & 4.37 \\
\hline 3 & I do meaningful assignments for students. & 1.05 & 3.91 \\
\hline 4 & I evaluate learning through academic achievement. & .94 & 4.21 \\
\hline 5 & I attend workshops/seminars/training to enhance my teaching skills. & .88 & 4.16 \\
\hline 6 & I analyze the assessments given. & 1.34 & 3.52 \\
\hline 7 & I am fair in teaching and learning. & .94 & 4.12 \\
\hline 8 & I receive feedback from students. & .92 & 3.93 \\
\hline \multirow[t]{2}{*}{9} & I make improvements based on the feedback I receive. & .95 & 3.86 \\
\hline & Overall Professional Competency Score & & 4.03 \\
\hline & Personality Competence & & \\
\hline 1 & I obey all the rules of the school. & .96 & 3.99 \\
\hline 2 & I solve problems well in teaching and learning. & .89 & 4.14 \\
\hline 3 & I always act honestly in the teaching and learning process. & .96 & 4.18 \\
\hline 4 & I provide an example of the correct attitude to students. & .97 & 4.00 \\
\hline 5 & I act angrily when there are students who do not understand the learning material I teach. & 1.11 & 3.66 \\
\hline \multirow[t]{2}{*}{6} & I remind other teachers to carry out orders and avoid bans. & 1.01 & 3.89 \\
\hline & Overall Personality Competency Score & & 3.97 \\
\hline & 4IR learning & & \\
\hline 1 & $\begin{array}{c}\text { I use learning aids such as projectors, laptops/computers, smartphones, virtual reality (VR), and } \\
\text { others. }\end{array}$ & .89 & 4.04 \\
\hline 2 & I use a computer lab that has Internet access. & .92 & 3.94 \\
\hline 3 & I have skills related to digital technology/the Internet. & .97 & 4.09 \\
\hline 4 & I demonstrate effective facilitation skills in the use of technology. & 1.10 & 4.03 \\
\hline 5 & I use online applications such as Kahoot, etc., in learning methods. & 1.04 & 4.03 \\
\hline 6 & I use software such as Microsoft Office in the teaching and learning process. & .97 & 4.19 \\
\hline 7 & I search websites as a reference. & 1.04 & 3.92 \\
\hline 8 & $\begin{array}{l}\text { I provide information on applications that can be downloaded onto smartphones to help improve } \\
\text { students' search for information. }\end{array}$ & 1.20 & 3.61 \\
\hline 9 & I use open learning media on the Internet to improve student performance. & .90 & 4.17 \\
\hline \multirow[t]{2}{*}{10} & I control the use of digital/Internet technology by students. & .97 & 4.04 \\
\hline & Overall 4IR learning Score & & 4.00 \\
\hline
\end{tabular}




\section{Objective 2: To examine the effect of economics teachers' competencies on 4IR learning.}

Based on the correlation results in Table 4, there was a positive correlation between teacher competence and 4IR learning $[\mathrm{R}=.325, \underline{\mathrm{n}}=256, \mathrm{p}<.001]$ with moderate levels of teacher competence associated with moderate levels of 4IR learning. Therefore, the quality of education can be supported by a teacher's ability with regard to learning in 4IR era.

Table 4. Pearson Correlation Analysis Results - The Relationship between Economics Teacher Competencies and 4 IR Learning

\begin{tabular}{cccc}
\hline & & $\begin{array}{c}\text { Teacher } \\
\text { Competence }\end{array}$ & 4IR Learning \\
\hline $\begin{array}{c}\text { Teacher } \\
\text { Competen } \\
\text { ce }\end{array}$ & $\begin{array}{c}\text { Pearson } \\
\text { Correlation }\end{array}$ & 1 & .325 \\
& Sig.2 (tailed) & & .000 \\
4IR & $\mathrm{N}$ & 256 & 256 \\
Learning & $\begin{array}{c}\text { Pearson } \\
\text { Correlation }\end{array}$ & .325 & 1 \\
& Sig.2 (tailed) & .000 & \\
& $\mathrm{~N}$ & 256 & 256 \\
& & & \\
\hline
\end{tabular}

Level of sig (0.01)

Regression analyses were performed to examine the effect of independent variables (economics teachers competences) on the dependent variables (4IR learning). Regression result in Table 5 indicated that there was a significant effect between teacher competence and 4IR learning $\left[\mathrm{F}(1,254)=37.44, \mathrm{p}<.001, \mathrm{R}^{2}=.478\right]$.

Table 5. Regression Results

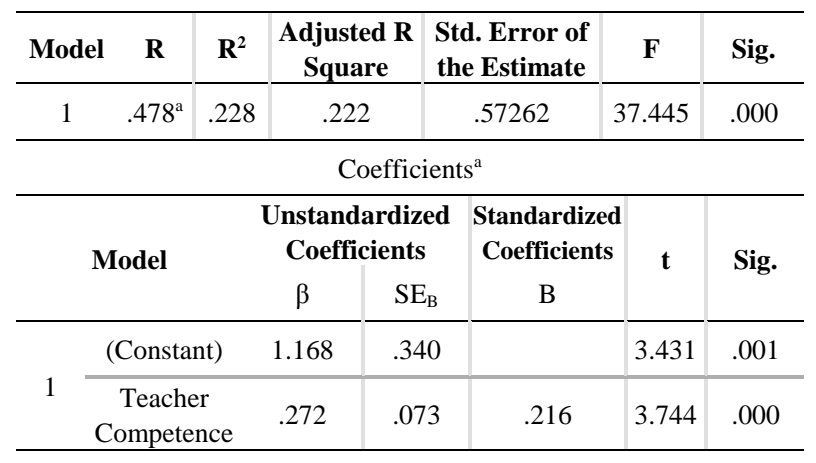

Dependent variables: 4IR Learning

Based on the regression result in Table 5, the influence of economics teachers' competencies can explain $47.8 \%$ of 4IR learning. Other factors explain the remaining $52.2 \%$. The results of the Anova test found that the value of $\mathrm{F}=$ 37.445 and $p<0.001$ show that the regression model could be used to predict 4IR learning. The regression equation is $\mathrm{Y}=$ Constant $+\beta 1 \mathrm{XI}$, where $\mathrm{Y}$ is 4IR Learning, $\mathrm{XI}$ is Teacher Competence. Thus, the regression equation for this test is 4IR Learning $=1.168+(0.272$ Teacher competence)

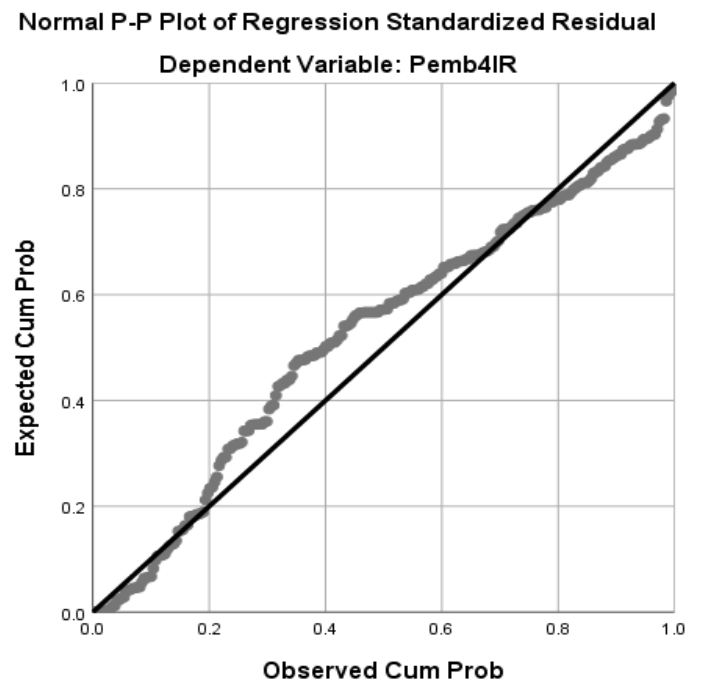

Figure 2. Plot of Regression Test

\section{Conclusions}

Based on the above discussion, this study has achieved its objective, which was to determine the level of competence of economics teachers in 4IR learning and also testing of the relationship between competencies of economics teachers and 4IR learning. Descriptive and Inferential analysis answered both research objectives in the study. This study only focused on economics teachers in Jakarta, Indonesia, with a sample of 256 teachers. The result of this study has statistically proved that economics teachers' competencies have a positive and significant impact on 4IR learning. This study also statistically proves the competency of teachers practiced at a high level with four constructs (specifically, pedagogical competency, social competency, professional competency, and personality competency) can act as a strategy to improve quality in 4IR learning, which also assist economics teachers in determining right learning strategies. However, to have practical and efficient learning in the learning process can be carried out following the prevailing curriculum targets. This study pointed out the essential thing for teachers to enhance their competencies because the more competent teachers it enriches students experiences and knowledge according to what is needed in the industrial revolution 4.0. Furthermore, learning processes can be designed with a focus on the relevant competencies and thereby expand the competency model's adequacy. The findings from this study can further be used as a starting point for teachers facing the challenges of Industry 4.0.

This situation also applies to the level of teachers competence; in the situation the level competency is high, it enhances the quality of teachers. Furthermore, a good school environment can support the 4IR learning process. Indirect effects of teachers has been found related to this 
study that teachers can also have more flexibility in designing their lessons creatively and supporting teachers to have a Critical Thinking to solve the problem in learning process. This study also provides basic implications for academics and industry for further study and it also has contributed as an additional literature on teacher competency in the context of Indonesia education. The researcher notes that research gaps have been identified, which indicate the direction of future research; evidence from industry should also be included.

In conclusion, referring to the above discussions, this study attempts to fill gaps in available knowledge, as discussed in the problem statement. This study also certainly has certain limitations. In this regard, it is hoped that this study can provide a preliminary reference for future studies related to teacher competence, school environment factors, and 4IR learning.

\section{Acknowledgement}

This research was funded by Universiti Kebangsaan Malaysia under grant: (GG-2019-038 and GGPM2018-004).

\section{REFERENCES}

[1] Afrianto, "Being a Professional Teacher in the Era of Industrial Revolution 4.0: Opportunities, Challenges and Strategies for Innovative Classroom Practices," Journal of English and Language Teaching and Research, 2(1), 2018.

[2] Anca, G. C., "The Gap between the Knowledge of Virtual Enterprise Actor and Knowledge Demand of Industri 4.0," daaam.proceedings, 105, 2017.

[3] C. Hewagamage and K.P. Hewagamage, "Developing ICT Competency among a large number of undergraduates in a University", Proceedings of 6th International Conference on Education and New Learning Technologies, Barcelona, Spain, 7-9 July, 2014.

[4] Creswell, J. W. Educational Research. New Jersey: Pearson, 2005.

[5] Creswell, J. W. Educational Research Planning: Conducting and Evaluating Quantitative and Qualitative Research. $3^{\text {rd }}$ Ed. New Jersey: Pearson, 2008.

[6] Dayangku Suraya Awang Jafar, Muhammad Sukri Saud, Mohd Zolkifli Abd Hamid , Nornazira Suhairom , Mohd
Hizwan Mohd Hisham , Yasmin Hanafi Zaid (2020). TVET Teacher Professional Competency Framework in Industry 4.0 Era. Universal Journal of Educational Research, 8(5), 1969 - 1979.

[7] Education Technology and Mobile Learning. 2016. 9 Fundamental Digital Skills for 21st Century Teachers. Available online: https://www.educatorstechnology.com/2016/12/9-fundame ntal-digital-skills-for-21st.html

[8] Hasnah Isnon, Jamaludin Badusah. Property of Universiti Kebangsaan Malaysia: Proficiency in Malay Language Teachers in Applying High Level Thinking Skills in Teaching and Learning. English Language Education Journal. ISSN: 2180-4842. Vol. 7, 2017.

[9] Kamarul, A. J. "Innovations in Teaching and Learning," in Kamarul Azmi Jasmi (Ed.), The Encyclopedia of Islamic Education. Skudai Johor: Faculty of Islamic Civilization, Universiti Teknologi Malaysia \& The Association of Islamic Education Scholars, 2016.

[10] Kiymet., S., "Teacher Competency," International Journal of Philosophy of Culture and Axiology, VII(1), 2016.

[11] Meylinda. Malaysian Higher Education System towards Industri 4.0 - Current Trend Overview. AIP Conference Proceedings, 020081, 2018.

[12] Muhd Khaizer Omar, Farah Nadia Zahar, Abdullah Mat Rashid (2020). Knowledge, Skills, and Attitudes as Predictors in Determining Teachers' Competency in Malaysian TVET Institutions. Universal Journal of Educational Research, 8(3C), 95 - 104

[13] Othman Talib, "SPSS: Data Analysis of Quantitative for Young Research,” MPWS Rich Publication Sdn Bhd : Bangi, 2016.

[14] Pallant, J., SPSS Survival Manual. McGraw-Hill Education (UK), 2011.

[15] Rosmani Ali, Nor Aishah Buang. "Property of Universiti Kebangsaan Malaysia: Entrepreneurial Competencies as Mediator of Readiness of Entrepreneurial Elements among the Lecturers of the Teacher Education Institute." Educational Journal of Malaysia. 43(3) SI: 123-130, 2018.

[16] Uno, Hamzah B. The Education Profession. Jakarta: Bumi Aksara Company, 2011.

[17] The law of numbered 14 years of 2005 about teachers and Dosen. Indonesian

[18] Z. Tasir, K.M.E. Amin, N.D.A. Halim and J. Harun, "Relationship Between Teachers' ICT Competency, Confidence Level, and Satisfaction toward ICT Training Programmes: A case study among postgraduate students", TOJET: The Turkish Online Journal of Educational Technology, Volume 11, Issue 1, 2012. 